\title{
AKIBAT HUKUM BAGI NOTARIS YANG MENOLAK PROTOKOL DARI NOTARIS LAIN
}

\author{
Roeri andriana*, Munsyarif Abdul Chalim ** \\ * Mahasiswa Program Magister (S2) Kenotariatan Fakultas Hukum UNISSULA, Semarang, e-mail: \\ roerinew02@gmail.com \\ ** Dosen Fakultas Hukum UNISSULA, Semarang
}

\begin{abstract}
Notary is a public official authorized to make an authentic deed to the extent that the making of such a certain authentic deed is not reserved for other general officials. The making of an authentic deed is required by law and regulation in order to create certainty, order and legal protection. In addition, the authentic deeds made by or before the notary are not only required by legislation, but also because it is desired by the parties concerned to ensure the rights and obligations of the parties. Notary became one of the general officials who provide services in the form of archiving files that have been done by the parties. What is meant by filing is to bind any legal acts committed by the parties in the notary's office. To achieve the objectives used legal juridical Normative research is the study of the law that focuses on the study of documents or bibliography, but to complement the data obtained from the study of documents or library then conducted field research, ie from the sources. Data analysis used is qualitative data analysis. Notary pursuant to Article 1 paragraph 1 of Law number 2 of 2014 concerning Position, Notary is a public official authorized to make authentic deeds and other authorities as referred to in this law. And still in Article 1 paragraph 13 UUJN (Position Notice Act) Protocol is a collection of documents that are archives of the state that should be kept and maintained by a notary. From the result of research and discussion it is concluded that rejecting protocol from other notary is not justified, because every notary must accept protocol from other notary it is stated in Notary Appointment Letter. Notary holder of the protocol shall only be responsible for securing state documents, submitting minas deed if necessary, in case of responsible criminal acts shall remain the notary making. It is stipulated in the Notary Office Law Article 65 that a notary, a substitute notary, a notary public official is responsible for every deed he has made even though the notary protocol has been transferred or transferred to the notary notary of the notary protocol. The rejection of the notary protocol is not an unlawful act, the unlawful act that exists in the notary profession is anything that is concerned with the product made by a notary (authentic deed). The supervision of a notary is conducted by the Minister by appointing the MPD (Regional Supervisory Council) in the case of notary protocol is the regional supervisory board to conduct reprentative and reprefentative supervision to impose administrative sanctions in the form of oral reprimands, written warning, dismissal, dismissal with respect and disrespect dismissal. Administrative sanctions are provided based on investigation team results, so MPW may impose sanctions on the notary who rejects the protocol.

Keywords: Notary Public, Notary Protocol, Notary Supervisory Board.
\end{abstract}

\section{PENDAHULUAN}

Dalam Negara Hukum perlindungan terhadap hak asasi manusia harus dijamin oleh Negara, di mana setiap warga negara mempunyai kedudukan yang sama dihadapan hukum dan pemerintah, ini merupakan konsekwensi prinsip kedaulatan rakyat serta prinsip negara hukum. Kepastian, ketertiban dan perlindungan hukum menuntut, antara lain bahwa lalu lintas hukum dalam kehidupan masyarakat memerlukan adanya alat bukti yang menentukan dengan jelas hak dan kewajiban seseorang sebagai subyek hukum dalam masyarakat.

Notaris adalah pejabat umum yang berwenang untuk membuat akta otentik sejauh mana pembuatan akta otentik tertentu tersebut tidak dikhususkan bagi pejabat umum lainnya. Pembuatan akta otentik diharuskan oleh peraturan perundang-undangan dalam rangka menciptakan kepastian, ketertiban dan 
perlindungan hukum. Selain itu akta otentik yang dibuat oleh atau dihadapan notaris, bukan saja karena diharuskan oleh peraturan perundangundangan, tetapi juga karena dikehendaki oleh pihak-pihak yang berkepentingan untuk memastikan hak dan kewajiban para pihak demi kepastian, ketertiban dan perlindungan hukum bagi pihak yang berkepentingan sekaligus bagi masyarakat secara keseluruhan.

Dapat kita ketahui bersama bahwa seorang notaris menjadi salah satu pejabat umum yang memberikan pelayanan berupa pengarsipan berkas-berkas yang telah di lakukan para pihak. Yang dimaksud dengan pengarsipan adalah membendel setiap perbuatan hukum yang dilakukan para pihak di kantor notaris tersebut. ${ }^{1}$

Dalam membuat akta autentik maka akan timbul juga minuta yang harus di simpan di kantor notaris yang bersangkutan, sehingga hal ini mengakibatkan menumpuknya minuta bagi seorang notaris. Yang kemudian menjadi pertanyaan adalah bagaimana nasib minuta tersebut setelah seorang telah berakhir masa jabatannya, berakhir karena di berhentikan dengan hormat (masa jabatannya telah berakhir, meninggal dunia) atau bahkan di berhentikan dengan tidak hormat maka minuta ini masuk kedalam protokol yang akan di limpahkan kepada notaris pengganti/berikutnya. Sehingga hal ini memunculkan pertanyaan bagaimana jika seorang notaris melakukan penolakan/tidak mau menerima protokol dari notaris lain yang dikarenakan selama menjabat notaris sebelumnya mungkin tidak profesional dalam menjalankan jabatannya. Sehingga ada kecemasan bagi notaris pengganti yang akan menerima protokol dari notaris sebelumnya.

Dalam menjalankan tugas jabatannya, salah satu kewajiban notaris dalam bidang administrasi adalah menyimpan dan memelihara segala dokumen termasuk diantaranya kumpulan akta dan berbagai dokumen lainnya yang biasa dikenal dengan protokol notaris. Menurut ketentuan yang disebut:

"Protokol Notaris adalah kumpulan

\footnotetext{
${ }^{1}$ http://www.duniaarsip.com/pengertian-arsipmenurut-undang-undang-nomor-7-tahun- 1971.html/, diakses pada 19 April 2017, jam 09.45WIB
}

dokumen yang merupakan arsip negara yang harus disimpan dan dipelihara oleh Notaris". ${ }^{2}$

Pengarsipan yang dilakukan seorang notaris pada hakikatnya adalah aset atau dokumen negara yang harus dipelihara/dijaga oleh seorang notaris itu sendiri. ${ }^{3}$ Pengertian kearsipan yaitu tata cara pengurusan penyimpanan warkat menurut aturan dan prosedur yang berlaku dengan mengingat 3 unsur pokok yang meliputi : penyimpanan, penempatan, dan penemuan kembali. ${ }^{4}$ Menurut uraian diatas dapat disimpulkan bahwa kearsipan adalah suatu proses kegiatan atau proses pengaturan mulai dari penerimaan, pencatatan, penyimpanan dengan menggunakan sistem tertentu, menemukan kembali dengan cepat dan tepat, penggunaan, pemeliharaan, penyusutan dan pemusnahan arsip. Penelitian ini berusaha untuk memahami Notaris yang menolak menerima Protokol atas Notaris yang pindah tempat kedudukan, pensiun atau meninggal dunia secara yuridis, artinya memahami objek penelitian sebagai hukum yakni sebagai kaidah hukum atau sebagai isi kaidah hukum sebagaimana yang ditentukan dalam peraturan perundang-undangan yang berlaku di Indonesia khusunya yang berkaitan dengan masalah Notaris pengganti, kewenangan, kewajiban dan larangan bagi Notaris pengganti maupun prosedur hukum atas berkas yang telah dikerjakan oleh Notaris sebelumnya ke Notaris pengganti.

Berdasarkan paparan dalam latar belakang diatas, penelitian ini berusaha menjawab pertanyaan mengenai : 1) Bagaimana akibat hukum bagi notaris yang menolak menerima protokol dari notaris lain?; Apakah jika seorang notaris menolak untuk menerima protokol dari notaris lain, apakah termasuk perbuatan melawan hukum?; Sejauh mana peran Majelis Pengawas Notaris dalam menangani penyerahan protokol notaris?

\footnotetext{
${ }^{2}$ Pasal 1 ayat 13 Undang-Undang nomor 2 tahun 2014

Tentang Jabatan Notaris

${ }^{3}$ Perkuliahan Semester 3 Mata Kuliah Cyber Administrasi Dosen Dr. Setyawati, SH., M.H pada hari Sabtu 15 April 2017

${ }^{4}$ The Liang Gie, Administrasi Perkantoran Modern, Yogyakarta, 2000, Liberty
} 


\section{METODE PENELITIAN}

Metode pendekatan yang digunakan dalam penelitian ini adalah metode pendekatan YuridisNormatif, yang dimaksud dengan pendekatan yuridis, adalah suatu cara yang digunakan dalam suatu penelitian yang mempergunakan asas-asas serta peraturan perundang-undangan guna meninjau, melihat serta menganalisis permasalahan yang ada di masyarakat, Pendekatan yuridis digunakan antara lain untuk menganalisis berbagai teori-teori hukum dan peraturan perundangundangan, terkait dengan akibat hukum bagi notaris yang menolak protokol dari notaris lain. Sedangkan metode penelitian Normatif merupakan penelitian hukum yang dilakukan dengan cara meneliti bahan pustaka atau data sekunder saja. ${ }^{5}$

Berdasarkan tujuan yang hendak dicapai pada penelitian ini maka hasil penelitian ini nantinya akan bersifat deskriptif analistis, yaitu memaparkan, menggambarkan atau mengurai fakta untuk memperoleh gambaran secara menyeluruh, permasalahan yang muncul, mengkaji dan merumuskan fakta hukum untuk mengetahui bagaimana hal tersebut kemudian dibahas atau dianalisis menurut ilmu dan teori-teori atau pendapat peneliti sendiri dan terakhir menyimpulkannya.

Data yang dikumpulkan dalam penelitian ini dapat digolongkan menjadi dua antara lain :

a. Data primer, berupa data-data yang didapatkan dalam penelitian dalam studi kepustakaan.

b. Data sekunder, data yang dipergunakan untuk melengkapi data primer.

Dalam data sekunder di lengkapi dengan bahan hukum primer, bahan hukum sekunder dan bahan hukum tersier.

Cara pengumpulan data akan dilakukan melalui:

a. Studi kepustakaan

Dengan mengumpulkan bahan pustaka yang didapat dari literatur atau buku-buku yang berkaitan dengan permasalahan dan peraturan

5 Salim.HS dan Erlies Septiana Nurbani, 2013, Penerapan Teori Hukum Pada Penelitian Tesis Dan Disertasi, RajaGrafindo Persada, Depok, h. 12 perundang-undangan dengan membaca, memahami dan mengutip bahan-bahan yang berkaitan dengan permasalahan.

b. Wawancara

Wawancara dengan melakukan tanya jawab dengan responden yang dijadikan sebagai narasumber dengan cara bebas terpimpin, yaitu pertanyaan hanya memuat garis besar yang akan mengarah pada permasalahan. Sistem wawancara yang dipakai adalah wawancara bebas terpimpin, artinya terlebih dahulu dipersiapkan daftar pertanyaan sebagai pedoman tetapi masih dimungkinkan adanya variasi pertanyaan yang disesuaikan dengan situasi pada saat wawancara dilakukan. ${ }^{6}$

Data yang sudah terkumpul baik data primer maupun data sekunder selanjutnya dilakukan proses editing dan kemudian dianalisis. Analisis data dilakukan dengan menggunakan analisis kualitatif. ${ }^{7}$ Analisis kualitatif merupakan analisis data yang tidak menggunakan angka, melainkan memberikan gambaran-gambaran (deskripsi) dengan kata-kata atas temuan-temuan, dan karenanya lebih mengutamakan mutu/kualitas dari data, dan bukan kuantitas. $^{8}$

\section{HASIL PENELITIAN DAN PEMBAHASAN}

Tugas pokok seorang notaris adalah membuat akta otentik. Adapun akta otentik menurut Pasal 1868 KUHPerdata adalah suatu akta yang didalam bentuk yang ditentukan oleh undang-undang, dibuat oleh atau dihadapan pegawai-pegawai umum yang berkuasa untuk itu di tempat dimana akta itu dibuatnya. Hal ini memberi pengertian bahwa notaris karena undang-undang diberi wewenang memberikan alat bukti yang mutlak, dalam pengertian bahwa apa yang tersebut didalam akta otentik itu pada pokoknya dianggap benar. ${ }^{9}$

6 Soetrisno Hadi, Metodologi Research Jilid II, (Yogyakarta: Yayasan Penerbit Fakulatas Psikologi UGM, 1985), h. 26

7 Lexy J. Moleong, 1989, Metode Penelitian Kualitatif, Rosda Karya, Bandung, hlm. 112

${ }^{8}$ Salim.HS dan Erlies Septiana Nurbani, Op. Cit., h. 19

9 Notodisoerjo, Soegondo, 1993, Hukum Notariat di Indonesia Suatu Penjelasan, PT. Raja Grafindo Persada, Jakarta, h. 8 
Sanksi yang dapat dikenakan kepada seorang notaris yang telah melanggar hukum yaitu :

\section{Sanksi Perdata}

Produk yang dikeluarkan seorang notaris yang berupa akta otentik merupakan alat bukti yang sangat kuat, mempunyai kekhususan bahwa apa yang dinyatakan dalam akta tersebut harus diterima, karenanya penggantian biaya, ganti rugi dan bunga tidak dapat secara otomatis dipaksakan kepada notaris tanpa melalui gugatan di pengadilan negeri. Yang termasuk dalam materi gugatan di pengadilan negeri adalah tidak terpenuhinya unsur-unsur pejabat pembuatannya dan/atau unsur tempat wilayah pembuatannya dan/atau unsur bentuk dan tata cara pembuatannya.

2. Sanksi Pidana

Seorang notaris dapat dituntut secara pidana apabila memberikan keterangan palsu dalam akta yang telah dibuatnya. ${ }^{10}$

3. Sanksi administrasi

Sanksi Administratif dilakukan secara langsung oleh instansi yang berwenang, sanksi ini berupa:
a. Teguran lisan
b. Teguran tertulis
c. Pemberhentian sementara
d. Pemberhentian dengan hormat
e. Pemberhentian tidak hormat

Tingkatan sanksi administratif diberlakukan melalui tahapan secara berurutan mulai dari teguran lisan, teguran tertulis, pemberhentian sementara, pemberhentian dengan hormat kemudian pemberhentian tidak hormat. Secara garis besaar sanksi administratif dapat dibedakan menjadi 3 (tiga) macam, yaitu: ${ }^{11}$

a. Sanksi Reparatif

Sanksi ini ditujukan untuk perbaikan atas pelanggaran tata tertib hukum. Dapat berupa penghentian perbuatan terlarang, kewajiban perubahan sikap/tindakan sehingga tercapai keadaan semula yang ditentukan, tindakan memperbaiki sesuatu yang berlawanan dengan

\footnotetext{
10 Prof. Moeljatno, SH, Pasal 242 Kitab Undang-Undang Hukum Pidana, PT. Bumi Aksara

${ }^{11}$ J.B.J.M. Ten Berge,1996, Besturen Door de Overheid, W.E.J. Tjeek Willink, Deventer, h. 390-391
}

aturan. Contoh: paksaan untuk berbuat sesuatu untuk pemerintah dan pembayaran uang paksa yang ditentukan sebagai hukuman.

b. Sanksi Punitif

Sanksi yang bersifat menghukum, merupakan beban tambahan. Sanksi hukuman tergolong dalam pembalasan, dan tindakan preventif yang menimbulkan ketakutan kepada pelanggar yang sama atau mungkin untuk pelanggar-pelanggar lainnya. Contoh: pembayaran denda kepada pemerintah, teguran keras.

c. Sanksi Regresif

Sanksi sebagai reaksi atas suatu ketidaktaatan, dicabutnya hak atas sesuatu yang diputuskan menurut hukum, seolah-olah dikembalikan kepada keadaan hukum yang sebenarnya sebelum keputusan diambil. Contoh: pencabutan, perubahan atau penangguhan suatu keputusan.

Seorang notaris wajib menerima protokol dari notaris sebelumnya, yang telah ditentukan/ ditunjuk oleh Majelis Pengawas Daerah. Sebagai notaris penerima protokol maka berkewajiban mengeluarkan Salinan Akta, Grosse di keluarkan. ${ }^{12}$ Protokol yang telah diserahkan kepada notaris pengganti bukan berarti membebaskan notaris dari tanggung jawabnya terhadap akta yang telah dibuatnya. Notaris penerima protokol hanya menerima dan menyimpan protokol dari notaris sebelumnya. Jika terjadi permasalahan terhadap akta tersebut, maka yang bertanggungjawab tetap notaris yang bersangkutan dan bukan notaris penerima protokol.

Menurut Dr. R. Wirjono Prodjodikoro, SH perbuatan melawan hukum adalah perbuatan yang mengakibatkan kegoncangan dalam neraca keseimbangan dalam masyarakat. ${ }^{13}$ Dalam profesi notaris tidak luput juga dari suatu permasalahan yang dapat berakibat pada perbuatan melawan hukum. Meskipun permasalahan tersebut tidak diinginkan oleh notaris. Sedangkan Pengertian pelanggaran yang ada dalam Kode Etik Notaris diatur dalam Pasal 1 angka 9 yaitu:

\footnotetext{
${ }^{12}$ Pasal 57

13 Wirjono Projodikoro,1994, Perbuatan Melanggar Hukum, Bandung: Sumur, h. 13
} 
"Pelanggaran adalah suatu tindakan yang dilakukan oleh perkumpulan maupun orang lain yang memangku dan menjalankan jabatan notaris yang melanggar ketentuan kode etik dan atau disiplin organisasi"

Jenis perbuatan melanggar hukum dalam profesi notaris :

1. Pidana

Seorang notaris dapat dikenakan tindakan pidana atas perbuatannya yang melanggar kaedah peraturan yang telah diterbitkan oleh negara. Hukum pidana adalah sekumpulan aturan yang menyangkut langsung mengenai ketertiban umum. Setiap perbuatan pidana selalu dirumuskan secara seksama dalam undang-undang sehingga sifatnya terbatas.

\section{Perdata}

Perbuatan melawan hukum dalam bidang perdata diatur dalam buku III Pasal 1352 KUHPerdata. Perbuatan melanggar hukum ada berasal dari undang-undang, bukan karena dari perjanjian yang didasarkan persetujuan dan perbuatan melawan hukum murni merupakan akibat perbuatan manusia yang sudah ditentukan sendiri oleh undang-undang.

3. Kode Etik \& UUJN

Menurut UUJN dan Kode Etik Notaris yang merupakan batasan suatu perbuatan hukum dalam profesi notaris secara formal atau perdata adalah apa yang mereka (notaris) lakukan terkait dengan tindakan-tindakan notaris seperti penambahan, pencoretan, pengubahan akta serta pembuatan akta yang tidak sesuai prosedur. Perbuatan melawan hukum menurut UUJN Pasal 48 hanya mengatur mengenai isi akta yang tidak boleh ditambah, baik berupa tulisan tumpang tindih, penyisipan, pencoretan yang dilakukan tanpa sepengetahuan para pihak. Hal tersebut sah jika para pihak menyetujui untuk melakukan perubahan pada akta, maka hasil dari perubahan akta tersebut harus ditandatangani, diparaf oleh para pihak, saksi dan notaris. ${ }^{14}$

Bentuk pelanggaran perbuatan melawan

\footnotetext{
${ }^{14}$ http://herman-notary.blogspot.com/2009/06/ perbedaan-wanprestasi-dengan-perbuatan.html, diakses pada 3 Juni 2017, pada jam 23.17 WIB
}

hukum dalam profesi notaris antara lain:

1. Akta dibuat tanpa dihadiri oleh saksi-saksi

2. Akta yang bersangkutan tidak dibacakan notaris

3. Akta yang bersangkutan tidak di tandatangani dihadapan notaris

4. Notaris membuat akta diluar wilayah jabatannya

5. Notaris membuka cabang dalam waktu yang bersamaan

Majelis pengawas Notaris sebagaimana diatur dalam Pasal 67 Undang-Undang Jabatan Notaris tentang Jabatan Notaris, bahwa dalam melaksanakan tugas jabatannya notaris perlu dilengkapi dengan pedoman untuk pengawasan terhadap notaris. Majelis Pengawas Notaris sendiri dibentuk oleh Menteri. Majelis Pengawas Notaris berjumlah 9 (sembilan) orang, terdiri dari:

a. Pemerintah sebanyak 3 (tiga) orang;

b. Organisasi Notaris sebanyak 3 (tiga) orang;

c. Ahli/akademisi sebanyak 3(tiga) orang.

Sebagaimana dalam Pasal 68 UUJN Pengawas Notaris terdiri dari Majelis Pengawas Daerah, Majelis Pengawas Wilayah dan Majelis Pengawas Pusat. Majelis Pengawas Notaris itu sendiri adalah suatu badan yang mempunyai kewenangan dan kewajiban untuk melaksanakan pembinaan dan pengawasan terhadap Notaris. ${ }^{15}$

Pasal 1 angka 1 Peraturan Menteri Hukum dan Hak Asasi Manusia Republik Indonesia Nomor: M.02.PR.08.10 Tahun 2004, menegaskan bahwa yang dimaksud dengan pengawasan adalah kegiatan yang berifat preventif dan kuratif termasuk kegiatan pembinaan yang dilakukan oleh Majelis Pengawas terhadap Notaris. Pengawasan yang dilakukan Majelis Pengawas tidak hanya pelasanaan tugas jabatan notaris agar sesuai dengan ketentuan UUJN, tetapi juga Kode Etik Notaris dan sikap dan prilaku kehidupan Notaris yang dapat mencederai keluhuran martabat Notaris. Pasal 67 ayat 5 UUJN menunjukkan bahwa ruang lingkup pengawasan yang dilakukan oleh Majelis Pengawas sangatlah luas.

Pasal 69 menerangkan bahwa dibentuk. MPD

\footnotetext{
15 Pasal 1 ayat 6 Undang-Undang Nomor 30 Tahun 2004 Tentang Jabatan Notaris
} 
merupakan tolak ukur dalam pengawasan notaris di tingkat bawah. Dalam ketentuan Pasal 66 UUJN ini adalah mutlak kewenangan Majelis Pengawas Daerah yang tidak dimiliki oleh Majelis Pengawas Wilayah maupun Majelis Pengawas Pusat. Ketentuan tersebut berlaku hanya dalam perkara pidana, karena dalam pasal tersebut berkaitan dengan tugas penyidik dan penuntut umum dalam ruang lingkup perkara pidana. Jika seorang notaris digugat perkara perdata maka izin dari MPD diperlukan, karena hak setiap orang untuk mengajukan gugatan jika ada hak-haknya terlarang oleh suatu akta notaris. Wewenang MPD (Majelis Pengawas Daerah) yang bersifat administratif yang memerlukan keputusan rapat MPD diatur dalam Pasal 14 Peraturan Menteri Hukum dan Hak Asasi Manusia Republik Indonesia Nomor: M.02.PR.08.10 Tahun 2004. Majelis Pengawas Daerah melakukan pemeriksaan secara berkala paling kurang sekali setahun terhadap notaris dengan melakukan pemeriksaan protokol notaris, memberikan ijin cuti selama 6 (enam) bulan dan pemeriksaan adanya laporan atau pengaduan dari masyarakat terhadap notaris. Apabila ada pengaduan dari masyarakat terhadap notaris yang melakukan pelanggaran kode etik maupun pelanaggaran UUJN, maka MPD berwenang menyelenggarakan sidang tertutup untuk umum, MPD akan memeriksa dan mendengar keterangan pelapor, tanggapan terlapor, memeriksa bukti yang diajukan pelapor dan terlapor, kemudian hasil pemeriksaan dituangkan dalam Berita Acara dan wajib diberikan kepada Majelis Pengawas Wilayah dalam 30 (tiga puluh) hari dengan tembusan kepada notaris yang bersangkutan, Pengurus Daerah Ikatan Notaris Indonesia dan Majelis Pengawas Pusat. MPD tidak berwenang memberikan penilaian pembuktian terhadap fakta-fakta hukum dan juga tanpa kewenangan untuk menjatuhkan sanksi.

Dalam penjatuhan sanksi terhadap notaris, jika berupa sanksi perdata dikarenakan akta notaris yang mempunyai kekuatan pembuktian sebagai akta dibawah tangan dan akta notaris demi hukum merupakan sanksi yang berkaitan dengan produk dari notaris yang diajukan oleh pihak atau penghadap yang namanya terssebut dalam aktau atau para ahli warisnya. Sanksi tersebut dijatuhkan karena notaris melanggar ketentuan Pasal 84 UUJN. Sedangkan sanksi administratif yang dijatuhkan oleh Majelis Pengawas karena Notaris melanggar ketentuanketentuan tertentu yang tersebut dalam Pasal 85 UUJN.

\section{KESIMPULAN DAN SARAN}

Berdasarkan hasil penelitian dan pembahasan pada bab sebelumnya maka dapat disimpulkan bahwa:

1. Akibat hukum bila terjadi penolakan dari Notaris untuk menerima Protokol dari Notaris lain adalah dengan adanya Sanksi Administratif. Pelanggaran oleh Notaris Pada Pasal 65 Undang-Undang Jabatan Notaris Nomor 2 tahun 2014 secara jelas menyebutkan bahwa Notaris, Notaris Pengganti, Notaris Pengganti Khusus dan Pejabat Sementara tetap bertanggungjawab atas setiap akta yang dibuatnya meskipun Protokol Notaris telah diserahkan atau dipindahkan kepada pihak penyimpan Protokol Notaris.

2. Menolak menerima Protokol Notaris termasuk dalam perbuatan melawan hukum, dan masuk dalam golongan pelanggaran Kode Etik Notaris yang dapat dikenakan sanksi administratif berupa teguran lisan atau teguran tertulis dari Majelis Pengawas Notaris yang bersifat internal.

3. Pengawasan terhadap Notaris yang dilakukan oleh majelis pengawas Daerah. Pengawasan Notaris dilakukan agar para Notaris dapat menjalankan jabatannya dengan lebih meningkatkan kualitas pelayanan kepada masyarakat dan prilaku Notaris sebagai pejabat umum. Pengawasan preventif dan represif diperlukan bagi pelaksanaan tugas Notaris.

\section{Saran}

1. Notaris diharapkan dalam menjalankan jabatannya selaku pejabat umum yang berwenang dalam pembuatan akta otentik, serta memahami dan melaksanakan ketentuanketentuan peraturan jabatan Notaris dan Undang-Undang Jabatan Notaris nomor 30 tahun 2004 sebagai pedoman dalam melaksanakan profesi Notaris. Notaris harus mampu berpsikap 
profesionalisme serta memahami aturan-aturan hukum yang terkait dengan pekerjaan Notaris yaitu dalam hal menerima Protokol Notaris diharapkan dalam pelaksanaan tugasnya, Notaris terhindar dari segala akibat hukum terhadap Protokol Notaris yang diterimanya. Untuk menyiasati penerimaan Protokol, maka sebaiknya Notaris penerima Protokol mendata minuta akta apa saja yang akan diterima, sehingga jelas apa yang diterima dan apa yang tidak diterima, sehingga jika dibutuhkan suatu hari sebagai alat bukti otentik dapat menunjukkan/ mengeluarkan atau tidak akta yang dibutuhkan.

2. Seharusnya Majelis Pengawas Notaris dalam menjalankan tugas dan jabatannya adalah pengawas yang memiliki pengetahuan dan mengerti tentang dunia kenotariatan khususnya dalam penerimaan Protokol dan juga memiliki integritas moral yang tinggi. Peran Majelis Pengawas harus lebih maksimal terutama MPD yang merupakan tolak ukur pengawasan yang merupakan pegawas dan pembina Notaris di daerah. Khususnya dalam memberikan sanksi bagi Notaris. Harus ada perbedaaan yang jelas mengenai peran dan fungsi Majelis Pengawas serta Majelis Kehormatan, agar tidak tumpang tindih kewenangan dilapangan.

3. Para penerima Protokol Notaris harus menyediakan tempat yang layak untuk mmenyimpan Protokol yang telah diterimanya, ada kemungkinan dalam beberapa tahun kedepan seiring semakin canggihnya teknologi maka minuta akta bisa berbentuk CD sehingga memudahkan dalam penyimpanan dan pencarian kembali jika dibutuhkan. Perlu adanya wacana pembuatan Protokol digital. Yang dapat mempermudah penyimpanan dan penemuan kembali Protokol yang dibutuhkan (=arsip negara). Dapat juga menghemat tempat penyimpanan karena tidak memperlukan ruang yang luas untuk cukup berbentuk CD, Disket dan/atau flasdisk yang dapat memuat hingga ratusan akta dalam 1(satu) tempat sekaligus aman dari bencana kebanjiran, kebakaran dan juga rayap yang bisa menghancurkan Protokol Notaris.
4. Hendaknya pengurus organisasi INI (Ikatan Notaris Indonesia) lebih intensif dalam mengadakan pertemuan dengan melibatkan unsur MPD (Majelis Pengawas Daerah)guna membahs masalah-masalah seputar pelaksaan jabatan Notaris khususnya yang berkaitan dengan kode etik dan undang-undang, sehingga para Notaris lebih mampu memahami dan mengerti tentang tugas dan jabatannya berkaitan dengan kode etik dan undang-undang. Selain itu juga mempererat hubungan antara sesama Notaris.

\section{DAFTAR PUSTAKA}

\section{BUKU}

Adjie, Habib, 2008, Hukum Notaris Indonesia (Tafsir Tematik Terhadap UU No. 30 Tahun 2004 Tentang Jabatan Notaris)

--------, 2008, Sanksi Perdata dan Administrasi Terhadap Notaris Sebagai Pejabat Publik, cet. 1, Riefka Aditama, Bandung

, 2009, Sekilas Dunia Notaris dan PPAT, Mandar Maju, Bandung

Anshori Abdul Ghofur, 2009, Lembaga Kenotariatan Indonesia Perspektif Hukum dan Etika, Yogyakarta; UII Press

Hadjon. Philipus. M, Penegakan Hukum Administrasi dalam Kaitannya dengan Ketentuan Pasal 20 ayat 3 dan 4 UU No. 4 Tahun 1982 Tentang Ketentuan-Ketentuan Pokok Pengelolaan Lingkungan Hidup, Yuridika, Fakultas Hukum Universitas Airlangga, No. 1 Tahun XI, JanuariPebruari 1996

, Pemerintahan Menurut Hukum, Yuridika, Cetakan I, Surabaya, 1992

dan Djamiati Tatiek Sri, 2005, Argumentasi Hukum, Gadjah Mada University Press, Yogyakarta

Gie The Liang, 2000, Administrasi Perkantoran Modern, Liberty, Yogyakarta. 
Kie, Tan Thong, Studi Notariat, Serba serbi Praktek Notaris, Buku I (Jakarta: PT. Ichtiar Baru Van Hoenve, 2000)

Manan, Bagir, 2004, Hukum Positif Indonesia, UII Press, Yogyakarta

Marzuki, Peter Mahmud, 2007, Penelitian Hukum, cet. 10, Kencana Prenada Media Group, Jakarta

Masriani, Yulis Tiena, 2008, Pengantar Hukum Indonesia, Sinar Grafika, Jakarta

M.A. Moegini Djojodirjo, 1982, Perbuatan Melawan Hukum, Jakarta: Pradnya Paramita

M.J.A. Van Mourik, Civil Law And The Civil Law Notary In A Modern World, Media Notariat

Notodisoerjo, R. Soegondo, 1993, Hukum Notariat di Indonesia Suatu Penjelasan, PT. Raja Grafindo Persada, Jakarta

Setiawan Rachmat, 1982, Tinjauan Elementer Perbuatan Melawan Hukum, Alumni, Bandung

Sukoco, Badir Munir, 2007, Manajemen Administrasi Perkantoran Modern, Erlangga

Suharso dan Retnoningsih Ana, Kamus Bahasa Indonesia, Edisi lux, cetakan kedelapan, (Semarang, Widya Karya, 2009)
Tedjosaputro Liliana, 1991, Malpraktek Notaris Dan Hukum Pidana, CV. Agung, Semarang,

Tobing, G.H.S Lumban, 1992, Peraturan Jabatan Notaris, Jakarta: Erlangga

2. Peraturan Perundang-undangan

Undang-Undang Nomor 2 tahun 2014 tentang Perubahan Atas Undang-Undang Nomor 30 Tahun 2004 tentang Peraturan Jabatan Notaris.

Keputusan Menteri Hukum dan Hak Asasi Manusia Republik Indonesia Nomor: M.39-PW.07.10 Tahun 2004 Tentang Pedoman Pelaksanaan Tugas Majelis Pengawas Notaris

Peraturan menteri hukum dan hak Hak Asasi Manusia Republik Indonesia Nomor: M.02.PR.08.10 Tahun 2004 Tentang Tata Carapengangkatan Anggota, Pemberhentian Anggota, Susunan Organisasi, Tata Kerja Dan Tata Kerja Pemeriksaan Majelis Pengawas Notaris

Peraturan Menteri Hukum Dan Hak Asasi Manusia Nomor 25 Tahun 2014 Tentang Syarat Dan Tata Cara Pengangkatan, Perpindahan, Pemberhentian, Dan Perpanjangan Masa Jabatan Notaris 